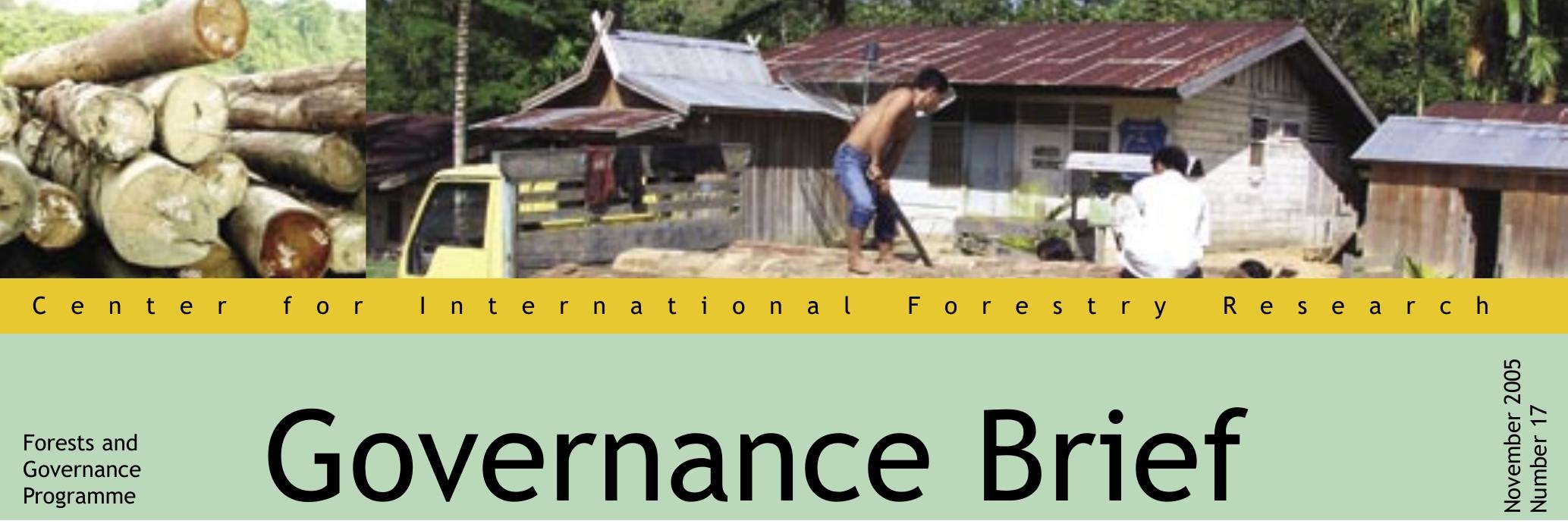

\title{
Menggunakan UU Tindak Pidana Pencucian Uang Menjerat Aktor Intelektual Illegal Logging
}

\section{Bambang Setiono}

Analis Kebijakan dan Keuangan, Pusat Riset Kehutanan Internasional (CIFOR)

\section{Sulitnya Memberantas Illegal logging}

Walaupun pemerintah pusat telah mengeluarkan berbagai inisiatif, termasuk operasi bersama melibatkan pejabat militer dan kepolisian, persoalan illegal logging terus muncul kepermukaan. Illegal logging sulit diberantas karena didukung oleh cukong yang beroperasi seperti sebuah organisasi kriminal dan terjadinya penyuapan dan korupsi yang melibatkan para pejabat yang berwenang dibidang kehutanan dan penegakan hukum. ${ }^{1}$ Para aktor intelektual ini sulit dijangkau dengan UU No.41 tahun 1999 tentang Kehutanan yang digunakan oleh penegak hukum untuk menjerat pelaku illegal logging. Sesuai dengan makna penebangan ilegal dalam UU tersebut, penegak hukum memfokuskan investigasinya kepada menemukan bukti fisik tentang penguasaan kayu ilegal. Karena fokusnya kepada pencarian bukti fisik, target yang paling cepat didapat oleh penegak hukum tentunya adalah pelaku di lapangan seperti supir truk yang mengangkut kayu tanpa dokumen yang sah. Namun, penegak hukum akan mengalami kesulitan untuk membuktikan adanya hubungan antara bukti fisik yang dibawa oleh supir tersebut dengan cukong kayu dan koruptor yang menjadi aktor intelektual illegal logging (Kapolda Sumut [2004]).

\section{Pencucian Uang dan Kejahatan Kehutanan}

Pada bulan Oktober 2003 pemerintah Indonesia merubah UU No.15/2002 mengenai tindak pidana pencucian uang (TPPU) menjadi UU No.25/2003 dan mencantumkan bahwa tindak pidana dibidang kehutanan dan lingkungan hidup sebagai kejahatan asal (predicate offences) yang dapat mengakibatkan terjadinya tindak pidana pencucian uang. Dengan perubahan ini, pemerintah Indonesia telah mengembangkan pendekatan baru dalam memerangi kejahatan dibidang kehutanan dan lingkungan.

\section{Definisi Pencucian Uang}

Pencucian uang adalah sebuah kejahatan yang melibatkan upaya untuk menyembunyikan atau menyamarkan hasil sebuah kejahatan. Para penjahat menyembunyikan atau menyamarkan hasil kejahatannya melalui proses: penempatan (placement), pelapisan (layering) atau penggabungan (integration).

'Placement' adalah sebuah tindakan dimana dana yang diperoleh dari hasil kejahatan ditempatkan atau disimpan didalam sistem keuangan, pada umumnya didalam sistem perbankan. Didalam proses placement terdapat pergerakan fisik uang.

Contoh placement terkait dengan kejahatan kehutanan:

- Uang tunai atau check hasil dari illegal logging atau korupsi disimpan didalam rekening di sebuah bank di sebuah kabupaten.

- Uang tunai atau check hasil illegal logging atau korupsi digunakan untuk membayar polis asuransi jiwa. 
diberikan kepada sebuah perusahaan sebagai korporasi adalah denda maksimal ditambah sepertiga. Selain hukuman denda, tambahan hukuman yang dapat diberikan kepada sebuah perusahaan adalah pencabutan izin usaha atau bahkan pembubaran dan likuidasi perusahaan atas keterlibatannya dalam kejahatan pencucian uang. ${ }^{2}$

\section{Pendekatan Anti Pencucian Uang}

Pendekatan anti pencucian uang meliputi enam tahap seperti berikut ini:

\section{PJK dan Prinsip Mengenal Nasabah (PMN)}

Bank dan penyedia jasa keuangan (PJK) lainnya harus memastikan tidak ada kriminal atau tersangka tindak kejahatan menyimpan uang hasil kejahatannya ke dalam sistem perbankan. PJK diminta untuk memahami profil dari nasabah mereka dan pola transaksi mereka termasuk nasabah yang bergerak dibidang kehutanan dengan menerapkan Prinsip Mengenal Nasabah (PMN). ${ }^{3}$ Kewajiban ini berlaku bagi nasabah baru maupun nasabah lama. PJK diminta untuk melalukan 'customer due diligence' (CDD) untuk mengetahui profil dari nasabahnya, paling tidak memiliki informasi tentang identitas, pekerjaan atau bidang usaha, pendapatan normal, rekening lain yang nasabah miliki, transaksi keuangan yang normal, dan tujuan membuka rekening atau menjalankan hubungan dengan PJK. ${ }^{4}$

\section{TKM dan TKT}

Apabila bank dan PJK lainnya menerapkan PMN dengan baik, mereka akan dapat mengidentifikasi transaksi keuangan yang mencurigakan (TKM) yang melibatkan nasabah mereka. Sebuah transaksi yang mencurigakan terjadi ketika seorang nasabah melakukan atau membatalkan transaksi keuangan dengan menggunakan harta yang diduga kuat (reasonably suspected) berasal dari hasil kejahatan. TKM juga terjadi jika transaksi keuangan nasabah menyimpang dari pola transaksi normal nasabah. ${ }^{5}$ PJK diwajibkan melaporkan transaksi mencurigakan (TKM) kepada Pusat Pelaporan dan Analisis Transaksi Keuangan (PPATK). Mereka juga harus melaporkan transaksi keuangan tunai (TKT) berjumlah Rp.500 juta atau lebih dalam satu hari.

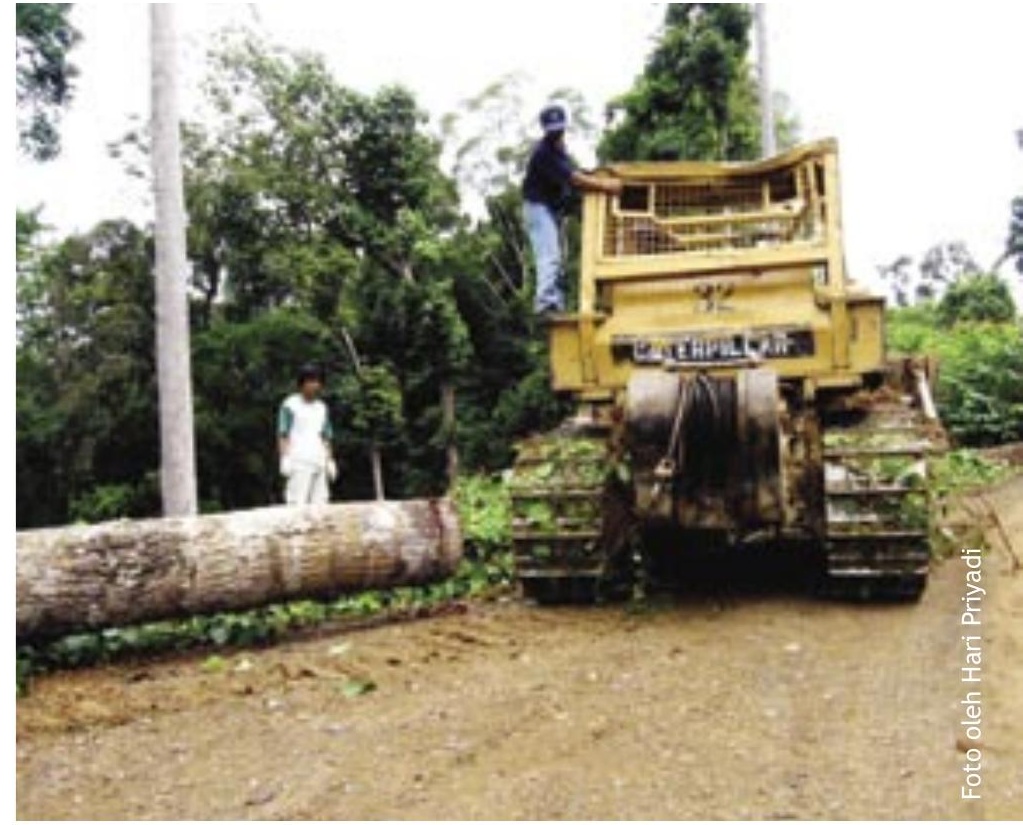

Kadang-kadang dapat pula bank dan PJK lainnya menerima informasi dari PPATK tentang nasabah mereka. Polisi yang telah banyak melakukan investigasi kasus illegal logging dan menduga adanya cukong dan aktor intelektual illegal logging dapat meminta PPATK untuk memberikan analisa intelijen keuangan atas tersangka cukong tersebut. PPATK kemudian membuat artifisial TKM dengan meminta PJK untuk melaporkan TKM atas nama cukong illegal logging yang diminta oleh PPATK. Artifisial TKM adalah TKM yang dibuat oleh PJK berdasarkan informasi yang disuplai oleh PPATK. Normal TKM adalah TKM yang dibuat sendiri oleh PJK berdasarkan informasi yang diperoleh dari sistem PMN yang diterapkan secara internal oleh PJK yang bersangkutan.

\section{PPATK}

Sebuah TKMharus dilaporkan paling lambat tiga hari kerja setelah sebuah bank mengetahui transaksi keuangan mencurigakan telah terjadi sementara TKM harus dilaporkan tidak lebih dari 14 hari kerja setelah transaksi dilakukan. ${ }^{6}$ Berdasarkan laporan ini, PPATK melakukan investigasi dan analisa keuangan atau transaksi untuk mencari indikasi adanya kejahatan pencucian uang. Hasil analisis keuangan ini kemudian akan diserahkannya kepada penyidik tindak pidana pencucian uang ataupun kepada pihak kejaksaan. ${ }^{7}$

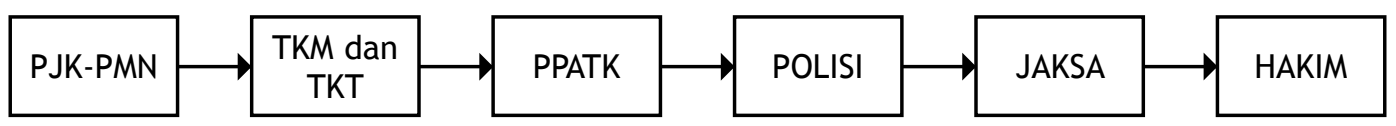


Didalam konteks penyidikan dan penuntutan terhadap aktor intelektual illegal logging, PPATK dapatmembantupihakpenyidikataupun penuntut umum untuk melakukan analisis atas transaksi keuangan yang melibatkan pihak dimaksud guna mengidentifikasi arus uang dalam investasi penebangan kayu dan proses pembayaran dari pembeli kayu kepada pemilik kayu. Informasi ini akan sangat penting bagi penyidik dan penuntut tindak pidana pencucian uang untuk memahami arus pencucian uang dan pihak-pihak terkait dengan tindak kejahatan penebangan kayu illegal..

\section{Pendekatan Baru Bagi Polisi, Jaksa dan Hakim}

UUTPPU sesungguhnya dapat digunakan untuk mengatasi kelemahan penegakan hukum kepada aktor intelektual illegal logging. UU ini memberikan terobosan-terobosan sebagai berikut:

- Kemudahan akses terhadap data keuangan tersangka tindak pidana pencucian uang. Kerahasiaan bank atau nasabah tidak berlaku jika nasabah dilaporkan oleh PJK berkaitan dengan kewajiban mereka berdasarkan UU TPPU kepada PPATK ataupun diduga terlibat kasus pencucian uang. Selain itu, penegak hukum dan hakim dapat langsung meminta data keuangan kepada PJK yang bersangkutan tentang pihak terlapor, tersangka, atau terdakwa. ${ }^{8}$

- Tidak perlu menunggu keputusan pengadilan untuk membuka data nasabah dan membekukan simpanan tersangka atau terdakwa di PJK yang bersangkutan. Penegak hukum tidak perlu membuktikan terlebih dahulu adanya tindak pidana asal (predicate offence) seperti adanya korupsi dan illegal logging. ${ }^{9}$

- Menggunakan alat bukti yang lebih banyak untuk membuktikan seseorang terlibat tindak pidana pencucian uang. UU TPPU juga menerima informasi dalam bentuk lisan dan tulisan yang tersimpan didalam bentuk elektronik sebagai alat bukti hukum termasuk peta, rancangan, photo, surat, dan tanda atau simbol. ${ }^{10}$

- Adanya azas pembuktian terbalik di pengadilan. Terdakwa pencucian uang mempunyaikewajibanuntukmembuktikan bahwa harta yang diperolehnya tidak berasal dari tindakan ilegal. ${ }^{11}$

- Memberikan perlindungan hukum kepada pihak pelapor dan saksi kasus pencucian uang. Prosedur perlindungan pelapor dan saksi dapat berbentuk menyembunyikan identitas saksi dan tidak mempertemukan saksi atau pelapor dengan tersangka secara langsung. ${ }^{12}$

Walaupun pendekatan anti pencucian uang diawali dengan adanya TKM ataupun TKT dari PJK dan analisa dari PPATK, penyidikan tindak pidana pencucian uang oleh Kepolisian Republik Indonesia dapat dimulai dengan adanya dugaan kuat dari penyidik bahwa seseorang atau suatu badan usaha telah melakukan tindakan menyembunyikan atau menyamarkan harta hasil kejahatan tanpa menunggu adanya laporan hasil analisis dari PPATK. Penyidik dapat mencapai kesimpulan ini berdasarkan hasil penyidikannya dalam perkara tindak pidana kejahatan asalnya seperti illegal logging dan korupsi. Koordinasi antara penyidik kejahatan illegal logging dan penyidik kejahatan pencucian uang merupakan hal yang sangat penting untuk segera menangkap aktor intelektual illegal logging.

\section{Kesimpulan dan Rekomendasi Kebijakan}

Paper ini menjelaskan tentang peluang dalam menggunakan UU TPPU untuk menjerat aktor intelektual tindak kejahatan illegal logging atau pencurian kayu. Seperti kita ketahui bersama illegal logging adalah sebuah kejahatan yang sangat kompleks untuk dipecahkan karena melibatkan berbagai pihak yang berkepentingan. Oleh karenanya, walaupun UU TPPU ini memberikan senjata untuk mengatasi kompleksitas masalah illegal logging, senjata ini tidak akan banyak bermanfaat jika dipegang oleh orang dan institusi yang tidak efektif. Berdasarkan pertimbangan tersebut, beberapa rekomendasi berikut ini diajukan.

1. DPR diharapkan memberikan dukungan hukum kepada operasional PPATK serta untuk memperoleh sumber daya yang cukup dalam rangka mengawasi lembaga keuangan dan memberikan kewenangan untuk menjatuhkan sanksi kepada PJK yang gagal menerapkan UU TPPU.

2. DPR perlu menilai efektivitas Kepolisian Republik Indonesia sebagai unjung tombak penanganan kasus pencucian uang dan mencari peluang untuk meningkatkan efektivitas rezim anti pencucian uang Indonesia.

3. PJK harus menyampaikan TKM kepada PPATK untuk nasabah yang telah dilaporkan oleh Menteri Kehutanan, Menteri Lingkungan Hidup, LSM, dan media massa karena terlibat tindak pidana dibidang kehutanan dan lingkungan, 
terutama mereka yang sudah berada dalam penyidikan kepolisian.

4. Polisi segera menggunakan UU TPPU untuk menjerat cukong pencurian kayu dari kasus-kasus pencurian kayu yang tengah mereka investigasi. Polisi dan Jaksa penuntut perlu mengembangkan sebuah pendekatan terpadu untuk menuntut tindak pidana pencucian uang baik secara independen maupun secara kumulatif dengan tindak pidana illegal logging.

5. Sistem anti pencucian uang seharusnya digunakan untuk mengurangi kejahatan asal. DPR perlu memberikan dukungan hukum agar PPATK diizinkan untuk memberikan hasil analisanya kepada pihak yang berwenang untuk tujuan memerangi kejahatan asal seperti kejahatan perbankan, korupsi, dan pencurian kayu.

\section{Daftar Pustaka}

Kepala Polisi Daerah Sumatera Utara, 2004, Penegakan Hukum dan Implementasi UU Tindak Pidana Pencucian Uang untuk mengatasi kejahatan kehutanan, paper disajikan di Seminar Implementasi UU TPPU, Medan, Mei 6.
Setiono, B. dan Husein, Y. 2005. Fighting Forestry Crimes and Promoting Prudent Banking for Sustainable Forest Management: the Anti-Money Laundering Approach, CIFOR Occasional Paper No.44, Bogor, Indonesia

\section{Catatan Kaki}

1 Berbagai laporan media massa dan LSM menyatakan kondisi ini, diantaranya Laporan the Last Frontier yang diterbitkan oleh Telapak dan EIA pada bulan Februari 2005

2 Pasal 4 dan 5, UU No.25/2003

${ }^{3}$ Lihat Governance Brief tentang penerapan PMN oleh PJK untuk penjelasan detail mengenai tahapan ini.

${ }^{4}$ Peraturan Bank Indonesia No. 3/23/PBI/2001 mengenai perubahan PBI No. 3/10/PBI/2001 mengenai prinsip mengenal nasabah.

${ }^{5}$ Pasal 1 ayat 7 , UU No. 25/2003.

${ }^{6}$ Pasal 13 ayat 2 dan 3, UU No. 25/2003

7 Pasal 26 huruf g UU No.25/2003

${ }^{8}$ Pasal 33 ayat 1 , UU No. 25/2003

${ }^{9}$ Penjelasan Pasal 3, paragraf 1, UU No. 25/2003

${ }_{10}$ Pasal 38, UU No. 25/2003

11 Pasal 35, UU No. 25/2003

12 Pasal 1 sampai 4, PP No. 57/2003 mengenai prosedur perlindungan khusus kepada pihak pelapor dan saksi tindak pidana pencucian uang. 


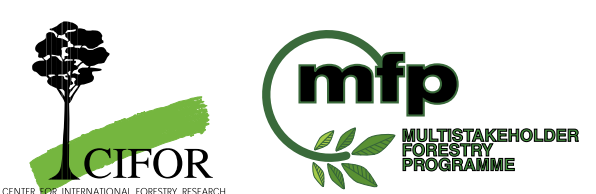

Center for International Forestry Research, CIFOR

Tel: +62(251) 622622 Fax: +62(251) 622100

E-mail: cifor@cgiar.org

Website: www.cifor.cgiar.org

Bogor Barat 16680, Indonesia.

Alamat surat: P.O. Box. 6596 JKPWB, Jakarta 10065

Indonesia

Foto sampul oleh: Petrus Gunarso dan Carol J.P. Colfer

Program Forests and Governance di CIFOR mengkaji cara pengambilan dan pelaksanaan keputusan berkenaan dengan hutan dan masyarakat yang hidupnya bergantung dari hutan. Tujuannya adalah meningkatkan peran serta dan pemberdayaan kelompok masyarakat yang kurang berdaya, meningkatkan tanggung jawab dan transparansi pembuat keputusan dan kelompok yang lebih berdaya dan mendukung proses-proses yang demokratis dan inklusif yang meningkatkan keterwakilan dan pengambilan keputusan yang adil di antara semua pihak. 